\title{
Karakteristik Organoleptik dan Total Mikroba Telur Ayam Ras yang Direndam dalam Air Rebusan Daun Melinjo (Gnetum gnemon L.)
}

\author{
Linda Novitanti, Suharyanto ${ }^{1}$, Edi Soetrisno ${ }^{1}$ dan Warnoto ${ }^{1}$ \\ ${ }^{1}$ Jurusan Peternakan Fakultas Pertanian Universitas Bengkulu \\ Jalan Raya W R.Supratman Kandang Limun Bengkulu \\ *Penulis korespondensi : suharyanto@unib.ac.id
}

Artikel ini diterima (received): 29 April 2021; dinyatakan disetujui (accepted): 28 Mei 2021; terbit (published): 30 Mei 2021. Artikel ini dipublikasi secara daring pada https://ejournal.unib.ac.id/index.php/buletin pt/index

\begin{abstract}
Abstrak
Penelitian ini bertujuan untuk mengetahui pengaruh perendaman telur ayam ras di dalam air rebusan daun melinjo terhadap karakteristik organoleptik (mutu hedonik dan hedonik), warna kuning, $\mathrm{pH}$ dan total mikroba pada telur ayam ras. Penelitian dilaksanakan pada tanggal 23 November 2020 s.d. 15 Januari 2021 di Laboratorium Peternakan, Jurusan Peternakan Universitas Bengkulu dan Laboratorium Kesmavet Dinas Peternakan dan Kesehatan Hewan Provinsi Bengkulu. Rancangan percobaan yang digunakan adalah Rancangan Acak Lengkap (RAL) dengan 4 perlakuan dan 4 ulangan yang diamati selama penyimpanan 14 dan 21 hari. Perlakuan terdiri atas P0: 0\%, P1: 15\%, P2: 30\%, P3: 45\% air rebusan daun melinjo (Gnetum gnemon $L$ ). Variabel yang diamati yaitu organoleptik meliputi bau, tekstur dan rasa, warna kuning; $\mathrm{pH}$ dan total mikroba isi telur. Hasil pengujian mutu hedonik dan hedonik bau menunjukkan bahwa perlakuan P2 dan P3 penyimpanan 21 hari mempengaruhi nilai dan kesukaan bau telur mentah maupun masak. Mutu hedonik dan hedonik tekstur menunjukkan bahwa semua perlakuan pada penyimpanan 14 dan 21 hari tidak meningkatkan nilai dan kesukaan tekstur putih telur maupun kuning telur. Mutu hedonik dan hedonik rasa menunjukkan bahwa perlakuan perlakuan P3 penyimpanan 14 hari dan semua perlakuan P2 dan P3 penyimpanan 21 hari mempengaruhi nilai dan kesukaan rasa putih telur maupun kuning telur. Hasil pengujian warna menunjukkan bahwa perlakuan P2 dan P3 penyimpanan 14 hari serta perlakuan P1, P2 dan P3 penyimpanan 21 hari dapat meningkatkan warna kuning telur. Hasil pengukuran pH menunjukkan bahwa lama penyimpanan menyebabkan terjadinya peningkatan nilai $\mathrm{pH}$. Hasil pengukuran TPC menunjukkan bahwa lama penyimpanan menyebabkan terjadinya kenaikan nilai TPC. Kesimpulanya adalah perendaman telur ke dalam air rebusan daun melinjo memengaruhi sifat organoleptik telur, meningkatkan tingkat kekuningan yolk, dan menurunkan jumlah mikroba.
\end{abstract}

Kata kunci: melinjo, organoleptik, telur, total mikroba.

\section{Pendahuluan}

Telur merupakan salah satu bahan pangan hasil ternak yang dibutuhkan oleh tubuh karena bernilai gizi tinggi. Telur memiliki kandungan gizi yang lengkap mulai dari protein, lemak, vitamin, dan mineral. Kandungan asam amino essensial yang lengkap menjadikan telur sebagai patokan dalam menentukan mutu protein berbagai bahan pangan (Indrawan et al., 2012). Telur mengandung banyak nutrisi dan tertinggi terdapat pada bagian kuningnya. Kuning telur mengandung asam amino esensial dan mineral yang dibutuhkan oleh tubuh seperti besi, fosfor, sedikit kalsium, vitamin B kompleks, protein dan lemak (Respati et al., 2013).

Telur mudah mengalami penurunan kualitas yang disebabkan oleh kerusakan secara fisik maupun non fisik seperti penguapan air, karbondioksida, amonia, nitrogen dan hidrogen sulfida dari dalam telur. Telur memiliki daya simpan yang pendek dalam suhu ruang dan hanya dapat bertahan selama $10-14$ hari tanpa 
adanya perlakuan pergawetan (Muchtadi et al., 2010). Namun seiring dengan bertambahnya umur simpan, kualitas telur akan menurun. Salah satu cara untuk mempertahankan kualitas telur adalah dengan melapisi dengan larutan seperti air kapur, larutan garam dan filtrat atau penyamak nabati. Salah satu larutan yang dapat digunakan sebagai penyamak nabati adalah air rebusan daun melinjo (Haryoto, 2010).

Aditama (2005) menyebutkan bahwa senyawa yang terkandung dalam daun melinjo diantaranya yaitu saponin, flavonoid dan tanin serta mengandung resveratrol yang memiliki sifat antibakteri dan antioksidan. Menuut Lestari et al. (2012), daun melinjo mengandung tanin sebesar 4,55\% dan ini dapat digunakan pada pengawetan telur ayam ras. Tanin akan bereaksi dengan protein yang terdapat dalam kulit telur yang mempunyai sifat seperti kolagen sehingga terjadi proses penyamakan berupa endapan berwarna coklat yang menutup pori-pori kulit telur sehingga kulit telur menjadi impermeable (tidak dapat tembus) terhadap gas dan udara, masuknya mikroorganisme ke dalam telur, penguapan serta hilangnya $\mathrm{CO}_{2}$ dapat dicega. Penggunaan ekstrak daun melinjo 20\% dan $30 \%$ sebagai penyamak dapat memperbaiki kualitas eksternal dan internal telur ayam ras Lestari et al. (2012). Perendaman telur selama 24 jam menggunakan ekstrak daun melinjo dapat mempertahankan kualitas dan daya simpan telur (Sudaryani, 2003).

Penelitian ini mengkaji pemanfaatan daun melinjo (Gnetum gnemon L.) sebagai alternatif pengawetan telur ayam ras untuk menghasilkan telur yang dapat bertahan lebih lama dan memiliki kualitas yang baik. Salah satu syarat penting pada kualitas produk hasil ternak adalah harus bebas dari bakteri. Salmonellosis adalah salah satu penyakit pada sistem pencernaan yang timbul akibat infeksi bakteri Salmonella sp di dalam usus. Bakteri ini adalah salah satu penyebab diare yang paling umum Manusia seringnya terinfeksi akibat dari mengonsumsi makanan atau air yang terkontaminasi oleh bakteri Salmonella sp. Penelitian ini bertujuan untuk mengevaluasi pengaruh perendaman telur ayam ras dalam air rebusan daun melinjo (Gnetum gnemon L.) terhadap karakteristik organoleptik (mutu hedonik dan hedonik), warna kuning telur, nilai $\mathrm{pH}$ dan total mikroba pada telur ayam ras

\section{Bahan dan Metode}

Alat yang digunakan dalam penelitian ini meliputi: ember, timbangan analitik, timbangan biasa, dandang, kompor, wajan, talenan, alat pengaduk, saringan, toples, rak telur (egg tray), cawan petri, tabung reaksi, erlenmeyer, pipet volumetrik, mikropipet dan tip, gunting, pinset, jarum inokulasi (ose), stomacher, bunsen, laminar, oven, labu ukur, pH meter digital, gelas ukur, vortex, inkubator, penangas air, autoklaf, lemari steril (clean bench), refrigerator, dan freezer.

Bahan yang digunakan dalam penelitian ini yaitu telur ayam ras, daun melinjo (Gnetum gnemon L.), air destilata, aquades, alcohol, PCA (Plate Count Agar) dan BPW (Buffered Peptone Water) 0,1\%.

Penelitian ini dilakukan dengan beberapa tahap antara lain: pengambilan sampel, pembuatan air rebusan daun melinjo dan perendaman telur.

\section{Pengambilan Sampel}

Sampel telur yang digunakan pada penelitian ini adalah telur ayam ras yang diperoleh dari peternak di Privinsi Bengkulu dan berumur tidak lebih dari 24 jam sebanyak 180 butir telur ayam ras. Telur ayam ras dibersihkan dengan lap yang dicelupkan pada air hangat, kemudian diletakkan pada eeg tray dan dikelompokkan sesuai dengan perlakuan.

Pembuatan Air Rebusan Daun Melinjo (Gnetum gnemon L.)

Daun melinjo (Gnetum gnemon L.) diperoleh dari wilayah Provinsi Bengkulu. Daun melinjo di timbang untuk mengetahui berat awal kemudian dibersihkan dari kotoran yang menempel, kemudian diiris kecil dengan ukuran $1 \mathrm{~cm}$, lalu dikeringanginkan pada suhu ruang $\left(28^{\circ} \mathrm{C}-30^{\circ} \mathrm{C}\right)$ dan dengan kelembaban $70 \%-80 \%$, selanjutnya ditimbang hingga berat konstan sebelum direbus (Karmila et al., 2008).

Konsentrasi daun melinjo yang digunakan pada penelitian ini adalah perbandingan $0 \%$ (b/v), 15\% (b/v), 30\% (b/v), dan 45\% (b/v) yaitu $0 \mathrm{~g}, 450 \mathrm{~g}, 900 \mathrm{~g}$, dan $1350 \mathrm{~g}$ daun melinjo yang masing-masing direbus dalam $3000 \mathrm{ml}$ air. 
Dalam pelayuan daun dengan metode perebusan, suhu yang terbaik dalam melakukan perebusan berkisar antara $80^{\circ} \mathrm{C}-90^{\circ} \mathrm{C}$.

\section{Perendaman Telur Ayam Ras}

Air rebusan daun melinjo didinginkan sampai suhunya $28{ }^{\circ} \mathrm{C}-30{ }^{\circ} \mathrm{C}$. Kemudian telur direndam selama 24 jam dalam toples yang berukuran 10 liter dan berisi $3000 \mathrm{ml}$ air rebusan daun melinjo, untuk kapasitas 45 butir telur dengan berbagai tingkatan perlakuan. Selanjutnya wadah ditutup rapat. Setelah 24 jam perendaman kemudian telur dikeringkan dengan cara ditaruh pada rak telur (egg tray) dan disimpan pada suhu ruang $\left(28^{\circ} \mathrm{C}-30^{\circ} \mathrm{C}\right)$ selama $14-21$ hari. Setelah 14 hari dan 21 hari kemudian telur yang akan digunakan untuk uji organoleptik direbus selama 15 menit pada suhu $80^{\circ} \mathrm{C}$ (Santoso, 2007).

\section{Rancangan Penelitian}

Rancangan penelitian yang digunakan adalah Rancangan Acak Lengkap (RAL) dengan 4 perlakuan, yaitu $\mathrm{P0}=$ tanpa perendaman; $\mathrm{P} 1=$ $15 \%, \mathrm{P} 2=30 \%$, dan $\mathrm{P} 3=45 \%$ air rebusan daun melinjo. Tiap perlakuan diulang 4 kali.

\section{Variabel yang Diamati}

Variabel yang diamati pada penelitian meliputi organoleptik (mutu hedonik dan hedonik), warna kuning telur, $\mathrm{pH}$ dan total mikroba isi telur.

\section{Organoleptik}

Karakteristik organoleptik ditentukan berdasarkan uji mutu hedonik dan hedonik. atribut sensorik meliputi bau, tekstur,dan rasa. Penilaian organoleptik dalam penelitian ini dilakukan oleh panelis yang berumur $20-22$ tahun sebanyak 25 orang. Panelis dipilih dari kalangan mahasiswa Jurusan Peternakan Fakultas Pertanian Universitas Bengkulu. Panelis akan diminta tanggapan atas sampel yang telah disediakan dengan memilih skor atribut. Atribut yang diamati adalah bau, rasa, dan tekstur. Parameter mutu hedonik disajikan pada tabel 1.

Untuk parameter atribut hedonik mencakup kesukaan dengan skor: 1 = sangat tidak suka, 2 = tidak suka, 3 = agak tidak suka, $4=$ netral, $5=$ agak suka, 6 = suka, 7 = sangat suka untuk semua atribut ditambah dengan penerimaan umum.
Untuk mengetahui kategori mutu hedonik dan hedonik maka dilakukan penentuan skala interval dengan rumus (Cooper dan Emory, 1996).

Skala Interval $=\frac{\mathrm{U}-\mathrm{L}}{\mathrm{K}}$, dimana $\mathrm{U}=$ skor tertinggi, $\mathrm{L}=$ skor terendah, dan $\mathrm{K}=$ jumlah kelas interval. Dari rumus di atas, maka skala interval yang digunakan untuk mutu hedonik (Tabel 2) dan hedonik (Tabel 3).

\section{Warna Kuning Telur}

Uji warna kuning telur diamati dengan cara memecahkan telur. Warna kuning telur dibandingkan dengan warna standar pada alat Roche Egg Yolk Colour Fan. Warna kuning telur diberi skor dengan nilai terendah 1 dan nilai tertinggi 15 dari warna pucat sampai orange tua/jingga. Warna kuning telur yang mendekati dengan salah satu warna pada alat tersebut merupakan angka skor warna kuning telurnya. Semakin jingga warna kuning telur maka semakin tinggi nilai kecerahannya.

$\mathrm{pH}$ Telur

Pengukuran $\mathrm{pH}$ telur dilakukan dengan metode AOAC (2005). Telur dipecahkan kemudian dikocok hingga homogen dan disiapkan sebanyak $2 \mathrm{ml}$. Sampel ditambahkan akuades $20 \mathrm{ml}$ dan dihomogenkan selama $3-5$ menit menggunakan vortex. Sampel dipindahkan ke dalam gelas ukur, pH-meter dicelupkan ke dalam sampel kira-kira $2-4 \mathrm{~cm}$. Nilai $\mathrm{pH}$ diperoleh dengan membaca skala yang ditunjukkan (8-10 menit).

\section{TPC (Total Plate Count) Isi Telur}

Penentuan TPC mengikuti Standar Nasional. Indonesia SNI 2897-2008. prosedur pengujian TPC (Total Plate Count) pada isi telur. Sebanyak $25 \mathrm{ml}$ sampel dimasukkan ke dalam plastik steril dan ditambahkan $45 \mathrm{ml}$ larutan Buffered Peptone Water (BPW) steril 0,1\% kemudian dihomogenkan menggunakan stomacher selama 1-2 menit (pengenceran 10 $10^{-1}$. Memindahkan $1 \mathrm{ml}$ suspensi pengenceran $10^{-1}$ tersebut dengan pipet steril ke dalam larutan 9 ml BPW untuk mendapatkan pengenceran $10^{-2}$, lalu homogenkan dengan vortex. Kemudian memindahkan $1 \mathrm{ml}$ suspensi pengenceran $10^{-2}$ dengan pipet steril ke dalam larutan $9 \mathrm{ml} \mathrm{BPW}$ untuk mendapatkan pengenceran $10^{-3}$. 
Tabel 1. Skor atribut mutu hedonik dan deskripsinya

\begin{tabular}{clll}
\hline Skor & \multicolumn{1}{c}{ Bau/aroma } & \multicolumn{1}{c}{ Rasa } & \multicolumn{1}{c}{ Tekstur } \\
\hline 1 & Sangat amis & Sangat tidak enak & Kasar \\
2 & Amis & Tidak enak & Agak kasar \\
3 & Agak amis & Agak enak & Agak lembut \\
4 & Tidak amis & Enak & Lembut \\
5 & Sangat tidak amis & Sangat enak & Sangat lembut \\
\hline
\end{tabular}

Sumber : Larmond (1970).

Tabel 2. Skala interval organoleptik mutu hedonik telur

\begin{tabular}{llll}
\hline Skor & Aroma & Rasa & Tekstur \\
\hline $1,00-1,79$ & Sangat Amis & Sangat Tidak Enak & Kasar \\
$1,80-2,59$ & Amis & Tidak Enak & Agak Kasar \\
$2,60-3,39$ & Agak Amis & Agak Enak & Agak Lembut \\
$3,40-4,19$ & Tidak Amis & Enak & Lembut \\
$4,20-5,00$ & Sangat Tidak Amis & Sangat Enak & Sangat Lembut \\
\hline
\end{tabular}

Tabel 3. Skala interval organoleptik kriteria hedonik

\begin{aligned} & \hline Skor Bau, Tekstur, Rasa \\ & \hline $1,00-1,85$ Sangat Tidak Suka \\ & $1,86-2,71$ Tidak Suka \\ & $2,72-3,57$ Agak Tidak Suka \\ & $3,58-4,43$ Netral \\ & $4,44-5,29$ Agak Suka \\ & $5,30-6,15$ Suka \\ & $6,16-7,00$ Sangat Suka \\ & \hline\end{aligned}

Selanjutnya masukkan sebanyak $1 \mathrm{ml}$ suspensi dari setiap pengenceran ke dalam cawan petri secara duplo. Menambahkan 15 $20 \mathrm{ml}$ Plate Count Agar (PCA) yang sudah didinginkan hingga temperatur $45{ }^{\circ} \mathrm{C}$ pada masing-masing cawan yang sudah berisi $1 \mathrm{ml}$ suspensi sampel dan dihomogenkan dengan digoyang lembut membentuk angka delapan, lalu diamkan hingga memadat. Cawan petri berisi sampel diinkubasi pada temperatur $34{ }^{\circ} \mathrm{C}$ - $36{ }^{\circ} \mathrm{C}$ selama $24-48$ jam dengan meletakkan cawan pada posisi terbalik. Perhitungan jumlah cemaran mikrob yang tumbuh dilakukan setelah inkubasi 24 jam. Cara perhitungan jumlah cemaran mikrob adalah: Jumlah bakteri = ratarata jumlah koloni $x$ faktor pengencer

\section{Analisis Data}

Data hasil pengujian organoleptik diuraikan secara deskriptif. Data total mikroba isi telur, warna kuning telur dan $\mathrm{pH}$ dianalisis dengan Anova. Apabila hasil analisis berpengaruh nyata
$(\mathrm{P}<0,05)$ terhadap peubah yang diamati, maka dilakukan uji DMRT (Duncan's Multiple Range Test).

\section{Hasil dan Pembahasan}

Sifat Organoleptik-Mutu Hedonik

Penilaian organoleptik (uji sensori) memiliki peranan penting dalam suatu produk pangan yang berkaitan dengan penerimaan konsumen terhadap produk pangan yang dihasilkan. Pada penelitian ini dilakukan penilaian organoleptik yang ditentukan dari uji mutu hedonik dan hedonik.

Bau

Hasil uji mutu hedonik bau telur ayam ras yang direndam dalam air rebusan daun melinjo (Gnetum gnemon L.) dapat dilihat pada Tabel 4. Rataan mutu hedonik bau putih telur mentah hari 14 berkisar 2,92 - 3,08 masuk dalam kategori yang sama yaitu agak amis, dan rataan pada hari 21 perlakuan P0 dan P1 lebih rendah yaitu berkisar 2,74-2,75 masuk dalam kategori yang sama yaitu agak amis, dibandingkan dengan perlakuan $\mathrm{P} 2$ dan $\mathrm{P} 3$ yaitu berkisar 3,42 - 3,49 masuk dalam kategori tidak amis. Rataan mutu hedonik bau kuning telur mentah hari 14 perlakuan P0, P1 dan P2 lebih rendah yaitu berkisar 2,88-3,03 masuk dalam kategori yang sama yaitu agak amis dibandingkan dengan P3 yaitu 3,45 masuk dalam kategori tidak amis, dan rataan pada hari 21 perlakuan P0 dan P1 lebih 
rendah yaitu berkisar 2,58-2,93 masuk dalam kategori yang sama yaitu agak amis dibandingkan dengan P2 dan P3 yaitu berkisar 3,51 - 3,60 masuk dalam kategori yang sama yaitu tidak amis.

Rataan mutu hedonik bau putih telur masak hari 14 berkisar 3,07 - 3,33 masuk dalam kategori yang sama yaitu agak amis, dan rataan pada hari 21 perlakuan P0 dan P1 lebih rendah yaitu berkisar 3,01 - 3,09 masuk dalam kategori yang sama yaitu agak amis dibandingkan dengan perlakuan P2 dan P3 yaitu berkisar 3,61 - 3,72 masuk dalam kategori tidak amis. Rataan mutu hedonik bau kuning telur masak hari 14 sberkisar 2,91-3,07 masuk dalam kategori yang sama yaitu agak amis, dan rataan pada hari 21 perlakuan P0 dan P1 lebih rendah yaitu berkisar 2,89 - 3,00 masuk dalam kategori yang sama yaitu agak amis dibandingkan dengan perlakuan P2 dan P3 yaitu berkisar 3,52 - 3,63 masuk dalam kategori yang sama yaitu tidak amis.

Hasil penelitian menunjukan bahwa penambahan persentase air rebusan daun melinjo perlakuan P2 dan P3 pada hari 21 dapat mempengaruhi bau putih dan kuning telur ayam ras mentah maupun masak dari amis menjadi tidak amis. Peningkatan bau ini diduga karena semakin banyak persentase air rebusan daun melinjo yang digunakan maka akan semakin besar juga persentase taninnya sehingga mempengaruhi bau putih dan kuning telur mentah maupun masak menjadi tidak amis (aroma tanin lebih dominan). Lupitasari et al. (2017) menyatakan bahwa pemberian ekstrak daun melinjo dengan konsentrasi $10 \%-20 \%$ menyebabkan aroma tanin lebih dominan sehingga lebih tercium. Diduga pada penelitian ini perendaman dengan konsentrasi yang lebih tinggi dan seiring dengan lama penyimpanan menyebabkan tanin lebih dominan sehingga mampu menutupi aroma amis.

\section{Tekstur}

Hasil uji mutu hedonik tekstur telur ayam ras yang direndam dalam air rebusan daun melinjo (Gnetum gnemon L.) dapat dilihat pada Tabel 5. Hasil penelitian menunjukkan bahwa perendaman telur ayam ras dalam air rebusan daun melinjo tidak mempengaruhi tekstur telur, dapat dilihat dari rataan skor panelis pada semua perlakuan dan waktu penyimpanan yang berkisar 2,90-3,38 masuk dalam kategori yang sama yaitu agak lembut. Hal ini menunjukkan bahwa tanin tidak mempengaruhi tekstur telur. Lupitasari et al. (2017) menyatakan bahwa pemberian ekstrak daun melinjo pada konsentrasi $10 \%$ - 20\% memberikan tekstur telur yang hampir sama. Tanin dari daun melinjo memiliki gugus polifenol dalam strukturnya sehingga dapat mengikat serta mengendapkan protein dari telur (Ismarani, 2012). Kesamaan waktu serta suhu pemasakan telur diduga menyebabkan jumlah protein terkoagulasinya sama sehingga menghasilkan tekstur yang sama.

Rasa

Hasil uji mutu hedonik rasa telur ayam ras yang direndam dalam air rebusan daun melinjo (Gnetum gnemon L.) dapat dilihat pada Tabel 6. Rataan mutu hedonik rasa putih dan kuning telur hari 14 perlakuan $\mathrm{P} 0, \mathrm{P} 1$ dan $\mathrm{P} 2$ lebih tinggi yaitu berkisar 3,41-3,64 masuk dalam kategori yang sama yaitu enak dibandingkan dengan perlakuan P3 yaitu berkisar 3,32 - 3,34 masuk dalam kategori sama yaitu agak enak. Rataan mutu hedonik rasa putih dan kuning telur hari 21 perlakuan P0 dan P1 lebih tinggi yaitu berkisar 3,02 - 3,11 masuk dalam kategori yang sama yaitu agak enak dibandingkan dengan prlakuan P2 dan P3 yaitu berkisar 2,17 - 2,59 masuk dalam kategori sama yaitu tidak enak.

Hasil penelitian menunjukkan bahwa pada hari 14, rasa putih dan kuning telur $\mathrm{P} 3$ menurun, demikian juga rasa putih dan kuning telur $\mathrm{P} 2$ dan P3 pada hari 21. Hal ini menunjukkan bahwa semakin besar persentase air rebusan daun melinjo dan semakin lama penyimpanan akan mempengaruhi rasa telur yang dihasilkan. Rasa agak enak pada putih dan kuning telur P3 hari 14 dan hari 21 serta rasa tidak enak pada putih dan kuning telur P2 dan P3 hari ke 14 dan hari ke 21 diduga karena tingginya kandungan tanin dalam telur sehingga menghasilkan rasa yang sepat. Lupitasari et al. (2017) menyebutkan bahwa perlakuan dengan konsentrasi $10 \%-20 \%$ ekstrak daun melinjo akan menyebabkan rasa sepat dari tanin semakin terasa seiring dengan meningkatnya konsentrasi. Rasa agak enak pada putih dan kuning telur hari 21 diduga karena dipengaruhi oleh lama penyimpanan. Sudaryani (2003) menyebutkan bahwa lama penyimpanan akan mempengaruhi kualitas telur dimana 
Tabel 4. Rataan mutu hedonik bau telur ayam ras yang direndam dalam air rebusan daun melinjo.

\begin{tabular}{lccccc}
\hline \multirow{2}{*}{ Parameter } & Pengamatan & \multicolumn{4}{c}{ Perlakuan } \\
\cline { 3 - 6 } Bau putih telur mentah & Hari ke-14 & $3,00(\mathrm{aa})$ & $3,03(\mathrm{aa})$ & $3,08(\mathrm{aa})$ & $2,92(\mathrm{aa})$ \\
& Hari ke-21 & $2,75(\mathrm{aa})$ & $2,74(\mathrm{aa})$ & $3,42(\mathrm{ta})$ & $3,49(\mathrm{ta})$ \\
\multirow{2}{*}{ Bau kuning telur mentah } & Hari ke-14 & $2,88(\mathrm{aa})$ & $2,94(\mathrm{aa})$ & $3,03(\mathrm{aa})$ & $3,45(\mathrm{ta})$ \\
& Hari ke-21 & $2,58(\mathrm{aa})$ & $2,93(\mathrm{aa})$ & $3,51(\mathrm{ta})$ & $3,60(\mathrm{ta})$ \\
\multirow{2}{*}{ Bau putih telur masak } & Hari ke-14 & $3,18(\mathrm{aa})$ & $3,33(\mathrm{aa})$ & $3,07(\mathrm{aa})$ & $3,23(\mathrm{aa})$ \\
& Hari ke-21 & $3,01(\mathrm{aa})$ & $3,09(\mathrm{aa})$ & $3,61(\mathrm{ta})$ & $3,72(\mathrm{ta})$ \\
Bau kuning telur masak & Hari ke-14 & $2,91(\mathrm{aa})$ & $3,01(\mathrm{aa})$ & $3,07(\mathrm{aa})$ & $3,00(\mathrm{aa})$ \\
& Hari ke-21 & $2,89(\mathrm{aa})$ & $3,00(\mathrm{aa})$ & $3,52(\mathrm{ta})$ & $3,63(\mathrm{ta})$ \\
\hline
\end{tabular}

Keterangan: aa: agak amis, ta: tidak amis

Tabel 5. Rataan mutu hedonik tekstur telur ayam ras yang direndam dalam air rebusan daun melinjo (Gnetum gnemon L.)

\begin{tabular}{llllll}
\hline \multirow{2}{*}{ Parameter } & \multirow{2}{*}{ Pengamatan } & Perlakuan & & \\
\cline { 3 - 6 } & & P0 & P1 & P2 & P3 \\
\hline \multirow{2}{*}{ Tekstur putih telur } & Hari ke-14 & $3,38(\mathrm{al})$ & $3,26(\mathrm{al})$ & $3,30(\mathrm{al})$ & $3,34(\mathrm{al})$ \\
\multirow{2}{*}{ Tekstur kuning telur } & Hari ke-21 & $3,25(\mathrm{al})$ & $3,30(\mathrm{al})$ & $3,34(\mathrm{al})$ & $3,35(\mathrm{al})$ \\
& Hari ke-14 & $3,31(\mathrm{al})$ & $3,38(\mathrm{al})$ & $3,06(\mathrm{al})$ & $3,16(\mathrm{al})$ \\
& Hari ke-21 & $2,90(\mathrm{al})$ & $3,20(\mathrm{al})$ & $3,32(\mathrm{al})$ & $3,32(\mathrm{al})$ \\
\hline
\end{tabular}

Keterangan: al: agak lembut.

Tabel 6. Rataan mutu hedonik tekstur telur ayam ras yang direndam dalam air rebusan daun melinjo

\begin{tabular}{llllll}
\hline \multirow{2}{*}{ Parameter } & \multirow{2}{*}{ Pengamatan } & \multicolumn{3}{l}{ Perlakuan } & \\
\cline { 3 - 6 } & & P0 & P1 & P2 & P3 \\
\hline \multirow{2}{*}{ Rasa putih telur } & Hari ke-14 & $3,57(\mathrm{e})$ & $3,64(\mathrm{e})$ & $3,53(\mathrm{e})$ & $3,32(\mathrm{ae})$ \\
& Hari ke-21 & $3,02(\mathrm{ae})$ & $3,07(\mathrm{ae})$ & $2,57(\mathrm{te})$ & $2,59(\mathrm{te})$ \\
\multirow{3}{*}{ Rasa kuning telur } & Hari ke-14 & $3,41(\mathrm{e})$ & $3,43(\mathrm{e})$ & $3,49(\mathrm{e})$ & $3,34(\mathrm{ae})$ \\
& Hari ke-21 & $3,11(\mathrm{ae})$ & $3,04(\mathrm{ae})$ & $2,39(\mathrm{te})$ & $2,17(\mathrm{te})$ \\
\hline
\end{tabular}

Keterangan: e: enak, ae: agak enak, te: tidak enak.

semakin lama waktu penyimpanan akan menyebabkan banyak penguapan cairan dan kantong udara akan semakin membesar sehingga menyebabkan rasa telur menjadi agak enak.

\section{Sifat Organoleptik-Hedonik}

Uji hedonik dilakukan untuk menetapkan kisaran nilai kesukaan panelis terhadap telur ayam ras yang direndam dalam air rebusan daun melinjo (Gnetum gnemon L.).

\section{Bau}

Hasil uji hedonik bau telur ayam ras yang direndam dalam air rebusan daun melinjo (Gnetum gnemon L.) dapat dilihat pada Tabel 7. Rataan hedonik bau putih telur mentah hari 14 berkisar 4,27-4,39 masuk dalam kategori yang sama yaitu netral, dan pada hari 21 perlakuan PO dan P1 lebih rendah yaitu berkisar 3,59-3,63 masuk dalam kategori yang sama yaitu netral dibandingkan dengan P2 dan P3 yaitu berkisar 4,58 - 5,03 masuk dalam kategori agak suka. Rataan hedonik bau kuning telur mentah hari 14 berkisar 4,72-4,88 masuk dalam kategori yang sama yaitu agak suka, dan rataan pada hari 21 perlakuan P0 dan P1 lebih rendah yaitu berkisar 3,58 - 3,66 masuk dalam kategori yang sama yaitu netral dibandingkan dengan perlakuan P2 dan P3 yaitu berkisar 4,47-4,91 masuk dalam kategori yang sama yaitu agak suka.

Rataan hedonik bau putih telur masak hari 14 berkisar 3,74-4,29 masuk dalam kategori yang sama yaitu netral, dan rataan pada hari 21 perlakuan P0 dan P1 lebih rendah yaitu berkisar 3,59 - 3,96 masuk dalam kategori yang sama 
yaitu netral dibandingkan dengan perlakuan P2 dan P3 yaitu berkisar 4,55-5,22 masuk dalam kategori agak suka. Rataan hedonik bau kuning telur masak hari 14 berkisar 4,53-4,89 masuk dalam kategori yang sama yaitu agak suka, dan rataan pada hari 21 perlakuan P0 dan P1 lebih rendah yaitu berkisar 3,78-3,84 masuk dalam kategori yang sama yaitu netral dibandingkan dengan perlakuan $\mathrm{P} 2$ dan $\mathrm{P} 3$ yaitu berkisar 4,46 - 4,64 masuk dalam kategori yang sama yaitu agak suka.

Hasil penelitian menunjukkan bahwa pada hari 14 pada semua perlakuan tidak meningkatkan kesukaan bau putih dan kuning telur mentah maupun masak, dan pada hari 21 perlakuan P2 dan P3 meningkatkan kesukaan bau putih dan kuning telur mentah maupun masak. Hal ini menunjukkan bahwa peningkatan persentase air rebusan daun melinjo perlakuan P2 dan P3 hari 21 dapat mempengaruhi tingkat kesukaan bau telur ayam ras dari netral menjadi agak suka (aroma tanin lebih dominan). Peningkatan tingkat kesukaan ini diduga karena semakin banyak persentase air rebusan daun melinjo yang digunakan maka akan semakin besar juga persentase taninnya sehingga mempengaruhi bau putih dan kuning telur mentah maupun masak menjadi suka (aroma tanin lebih dominan). Lupitasari et al. (2017) menyatakan bahwa pemberian ekstrak daun melinjo dengan konsentrasi $10 \%-20 \%$ menyebabkan aroma tanin lebih dominan sehingga lebih tercium. Diduga pada penelitian ini perendaman pada konsentrasi yang lebih tinggi menyebabkan tanin lebih dominan dan mampu menutupi aroma amis.

\section{Tekstur}

Hasil uji hedonik tekstur telur ayam ras yang direndam dalam air rebusan daun melinjo (Gnetum gnemon L.) dapat dilihat pada Tabel 8. Hasil penelitian menunjukkan bahwa perendaman telur ayam ras dalam air rebusan daun melinjo tidak mempengaruhi tingkat kesukaan tekstur telur. Hal ini dapat dilihat dari rataan skor panelis pada semua perlakuan dan waktu penyimpanan yang berkisar 3,64- 4,29 masuk dalam kategori yang sama yaitu netral. Hal ini menunjukkan bahwa tanin tidak mempengaruhi tekstur telur. Lupitasari et al. (2017) menyatakan bahwa pemberian ekstrak daun melinjo pada konsentrasi $10-20 \%$ memberikan tingkat kesukaan tekstur telur yang hampir sama. Tanin dari daun melinjo memiliki gugus polifenol dalam strukturnya sehingga dapat mengikat serta mengendapkan protein dari telur (Ismarani, 2012). Kesamaan waktu serta suhu pemasakan telur diduga menyebabkan jumlah protein terkoagulasinya sama sehingga menghasilkan tekstur yang sama.

Rasa

Hasil uji hedonik rasa telur ayam ras yang direndam dalam air rebusan daun melinjo (Gnetum gnemon L.) dapat dilihat pada Tabel 9. Rataan hedonik rasa putih dan kuning telur hari 14 perlakuan P0, P1 dan P2 lebih tinggi yaitu berkisar 4,83-5,19 masuk dalam kategori yang sama yaitu agak suka, dibandingkan dengan perlakuan P3 yaitu berkisar 4,40-4,41 masuk dalam kategori sama yaitu netral, dan rataan hari 21 perlakuan P0 dan P1 lebih tinggi yaitu berkisar 3,58-4,36 masuk dalam kategori yang sama yaitu netral dibandingkan dengan perlakuan P2 dan P3 yaitu berkisar 3,42-3,49 masuk dalam kategori sama yaitu agak tidak suka.

Hasil penelitian menunjukkan bahwa pada hari 14, rasa putih dan kuning telur P3 menurun, demikian juga rasa putih dan kuning telur $\mathrm{P} 2$ dan P3 pada hari 21. Hal ini menunjukkan bahwa semakin besar persentase air rebusan daun melinjo dan semakin lama penyimpanan akan mempengaruhi rasa telur yang dihasilkan. Rasa agak enak pada putih dan kuning telur $\mathrm{P} 3$ hari 14 dan hari 21 serta rasa tidak enak pada putih dan kuning telur P2 dan P3 hari ke 14 dan hari ke 21 diduga karena tingginya kandungan tanin dalam telur sehingga menghasilkan rasa yang sepat. Hasil penelitian Lupitasari et al. (2017) menyebutkan bahwa perlakuan dengan konsentrasi $10 \%$ - $20 \%$ ekstrak daun melinjo menyebabkan rasa sepat dari tanin semakin terasa seiring dengan peningkatan konsentrasi. Selain itu, menurut Sudaryani (2003) lama penyimpanan akan mempengaruhi kualitas telur dimana semakin lama waktu penyimpanan akan menyebabkan banyak penguapan cairan dan kantong udara akan semakin membesar sehingga menyebabkan rasa telur menjadi tidak enak. 
Tabel 7. Rataan hedonik bau telur ayam ras yang direndam dalam air rebusan daun melinjo.

\begin{tabular}{|c|c|c|c|c|c|}
\hline \multirow{2}{*}{ Parameter } & \multirow{2}{*}{ Pengamatan } & \multicolumn{4}{|l|}{ Perlakuan } \\
\hline & & PO & $\mathrm{P} 1$ & $\mathrm{P} 2$ & P3 \\
\hline \multirow{2}{*}{ Bau putih telur mentah } & Hari ke-14 & $4,27(n)$ & $4,28(n)$ & $4,39(n)$ & $4,33(n)$ \\
\hline & Hari ke-21 & $3,59(n)$ & $3,63(n)$ & 4,58 (as) & 5,03 (as) \\
\hline \multirow{2}{*}{ Bau kuning telur mentah } & Hari ke-14 & 4,79 (as) & 4,77 (as) & 4,88 (as) & 4,72 (as) \\
\hline & Hari ke-21 & $3,66(n)$ & $3,58(n)$ & 4,47 (as) & 4,91 (as) \\
\hline \multirow{2}{*}{ Bau putih telur masak } & Hari ke-14 & $3,74(n)$ & $3,82(n)$ & $3,78(n)$ & $4,29(n)$ \\
\hline & Hari ke-21 & $3,96(n)$ & $3,59(n)$ & 4,55 (as) & 5,22 (as) \\
\hline \multirow{2}{*}{ Bau kuning telur masak } & Hari ke-14 & 4,79 (as) & 4,89 (as) & 4,69 (as) & 4,53 (as) \\
\hline & Hari ke-21 & $3,84(n)$ & $3,78(n)$ & 4,64 (as) & 4,46 (as) \\
\hline
\end{tabular}

Keterangan:, n: netral, as: agak suka.

Tabel 8. Rataan tekstur hedonik bau telur ayam ras yang direndam dalam air rebusan daun melinjo.

\begin{tabular}{llllll}
\hline \multirow{2}{*}{ Parameter } & \multirow{2}{*}{ Pengamatan } & Perlakuan & & \\
\cline { 3 - 6 } & & P0 & P1 & P2 & P3 \\
\hline \multirow{2}{*}{ Tekstur putih telur } & Hari ke-14 & $4,29(n)$ & $4,26(n)$ & $4,05(n)$ & $4,42(n)$ \\
\multirow{2}{*}{ Tekstur kuning telur } & Hari ke-21 & $4,13(n)$ & $3,87(n)$ & $3,99(n)$ & $3,80(n)$ \\
& Hari ke-14 & $3,86(n)$ & $4,17(n)$ & $4,05(n)$ & $4,03(n)$ \\
& Hari ke-21 & $4,19(n)$ & $3,97(n)$ & $3,93(n)$ & $3,64(n)$ \\
\hline
\end{tabular}

Keterangan: n: netral.

Tabel 9. Rataan hedonik rasa telur ayam ras yang direndam dalam air rebusan daun melinjo.

\begin{tabular}{|c|c|c|c|c|c|}
\hline \multirow{2}{*}{ Parameter } & \multirow{2}{*}{ Pengamatan } & \multicolumn{4}{|l|}{ Perlakuan } \\
\hline & & PO & P1 & P2 & P3 \\
\hline \multirow{2}{*}{ Rasa putih telur } & Hari ke-14 & 4,83 (as) & 4,96 (as) & 4,99 (as) & $4,40(n)$ \\
\hline & Hari ke-21 & $3,95(n)$ & $3,58(n)$ & 3,47 (ats) & 3,42 (ats) \\
\hline \multirow{2}{*}{ Rasa kuning telur } & Hari ke-14 & 4,94 (as) & 4,86 (as) & 5,19 (as) & $4,41(n)$ \\
\hline & Hari ke-21 & $4,36(n)$ & $3,63(n)$ & 3,48 (ats) & 3,49 (ats) \\
\hline
\end{tabular}

Keterangan: as: agak suka, n: netral, ats: agak tidak suka.

\section{Warna Kuning Telur}

Pengukuran warna kuning telur dilakukan dengan menggunakan skala Roche, dimana skor warna kuning yang baik berkisar antara $7-12$ skala Roche (Stadelman and Cotteril, 1995). Hasil pengamatan warna kuning telur yang direndam dalam air rebusan daun melinjo dapat dilihat pada Tabel 10.

Skor warna kuning telur pada hari 14 perakuan P0 dan P1 adalah 7,25 lebih rendah dibandingkan dengan perlakuan $\mathrm{P} 2$ dan $\mathrm{P} 3$ yaitu berkisar 7,50-7,70, dan skor warna kuning telur hari 21 P0 lebih rendah yaitu 7,25 dibandingkan dengan perlakuan P1, P2 dan P3 yaitu berkisar 7,50 - 7,75. Penambahan persentase air rebusan daun melinjo P2 dan P3 hari 14 meningkatkan skor warna kuning telur sebesar $3,44 \%$ dan $6,21 \%$, pada hari 21 penambahan persentase air rebusan daun melinjo P1, P2 dan P3 meningkatkan skor warna kuning telur sebesar $3,44 \%$ dan $6,90 \%$. Hal ini menunjukkan bahwa penambahan persentase air rebusan daun melinjo dapat meningkatkan warna kuning telur. Adanya peningkatan warna kuning telur diduga disebabkan oleh semakin besar persentase air rebusan daun melinjo yang ditambahkan maka akan semakin besar senyawa tanin yang didapat. Senyawa tanin mengandung struktur fenol dimana salah satu sifat fenol adalah pemberi warna, sehingga semakin besar senyawa tanin yang didapat maka semakin besar fenol yang dapat masuk ke kuning telur dan menyebabkan perubahan warna kuning telur. Hal ini sejalan dengan pernyataan Nadjeeb (2010) dalam Yulianto 
Tabel 10. Hasil rataan pengamatan warna kuning telur ayam ras yang direndam dalam air rebusan daun melinjo

\begin{tabular}{lccccc}
\hline \multirow{2}{*}{ Parameter } & \multirow{2}{*}{ Pengamatan } & \multicolumn{4}{c}{ Perlakuan } \\
\cline { 3 - 6 } & & P0 & P1 & P2 & P3 \\
\hline \multirow{2}{*}{ Warna Kuning Telur } & Hari ke-14 & $7,25 \pm 0,50$ & $7,25 \pm 0,50$ & $7,50 \pm 0,58$ & $7,70 \pm 0,58$ \\
& Hari ke-21 & $7,25 \pm 0,50$ & $7,50 \pm 0,58$ & $7,50 \pm 0,58$ & $7,75 \pm 0,50$ \\
\hline
\end{tabular}

(2013) yang menyebutkan bahwa fenol dari tanin memiliki sifat antiseptik dan pemberi warna.

\section{pH Telur dan Log CFU/g TPC (Total Plate Count) Isi Telur}

Hasil uji pH dan TPC telur ayam ras yang direndam dalam air rebusan daun melinjo disajikan pada Tabel 11. $p H$ Telur

Hasil analisis ragam perendaman telur ayam ras dalam air rebusan daun melinjo terhadap $\mathrm{pH}$ telur ayam ras menunjukkan hasil yang berbeda nyata $(P<0,05)$ pada hari 14 maupun hari 21 . Rataan $\mathrm{pH}$ telur hari 14 dan hari 21 paling rendah pada perlakuan $\mathrm{P} 3$ yaitu 6,99 dan 7,12 dibandingkan dengan perlakuan PO yaitu 7,60 dan 7,72. Hasil penelitian $\mathrm{pH}$ menunjukkan bahwa semakin tinggi persentase air rebusan daun melinjo menyebabkan $\mathrm{pH}$ menurun. Hal ini diduga karena pori-pori tertutup oleh tanin sehingga penguapan berkurang yang menyebabkan $\mathrm{pH}$ menjadi turun, dan seiring dengan lama waktu penyimpanan akan menyebabkan terjadinya peningkatan nilai $\mathrm{pH}$. $\mathrm{pH}$ pada hari 21 cenderung lebih tinggi jika dibandingkan dengan hari 14 . Kenaikan pH diduga disebabkan karena peran tanin sebagai penyamak sehingga penguapan $\mathrm{CO}_{2}$ bersama dengan uap air yang keluar dari telur hanya sedikit, dimana kehilangan $\mathrm{CO}_{2}$ akan memicu kenaikan pH. Lestari et al. (2012), daun melinjo mengandung tanin sebesar 4,55\%. Dengan adanya kandungan tanin pada daun melinjo maka dapat digunakan pada pengawetan telur ayam ras. Tanin akan bereaksi dengan protein yang terdapat dalam kulit telur yang mempunyai sifat menyerupai kolagen kulit hewan sehingga terjadi proses penyamakan kulit berupa endapan berwarna coklat yang dapat menutup pori-pori kulit telur dan kulit telur tersebut menjadi impermeable (tidak dapat tembus) terhadap gas dan udara sehingga mampu memperkecil penguapan air serta hilangnya $\mathrm{CO} 2$ melalui kulit telur. Hal ini sesui dengan pendapat Hajrawati dan Answar (2011) yang menyatakan bahwa $\mathrm{pH}$ akan naik karena telur kehilangan $\mathrm{CO}_{2}$. Hilangnya gas $\mathrm{CO}_{2}$ pada telur menyebabkan konsentrasi ion bikarbonat menjadi turun dan sistem buffer menjadi rusak, sehingga akan mengakibatkan kenaikan pH (Harahap, 2007).

\section{Log CFU/mI TPC (Total Plate Count) Isi Telur}

Hasil analisis ragam Anova (Tabel 11) menunjukkan bahwa perendaman air rebusan daun melinjo serta lama waktu penyimpanan tidak memberikan pengaruh nyata terhadap nilai TPC telur ayam ras. Namun dapat dilihat dari rataan nilai TPC telur yang disimpan selama 14 hari yaitu PO $\left(2,6 \times 10^{3}\right), \mathrm{P} 1\left(2,5 \times 10^{3}\right), \mathrm{P} 2(2,5$ $\left.\times 10^{3}\right)$, dan $\mathrm{P} 3\left(2,5 \times 10^{3}\right)$, dan pada hari 21 yaitu P0 $\left(2,7 \times 10^{3}\right)$, P1 $\left(2,7 \times 10^{3}\right)$, P2 $\left(2,6 \times 10^{3}\right)$ dan P3 $\left(2,5 \times 10^{3}\right)$ menunjukkan bahwa lama penyimpanan hari 14 ke hari 21 terlihat adanya kenaikan jumlah mikroba namun menurun seiring dengan peningkatan persentase air rebusan daun melinjo pada lama penyimpanan yang sama.

Nilai TPC hari 14 paling rendah pada perlakuan $\mathrm{P} 3$ yaitu $2,5 \times 10^{3} \mathrm{CFU} / \mathrm{ml}$ dibandingkan dengan $\mathrm{PO}$ yaitu $2,6 \times 10^{3} \mathrm{CFU} / \mathrm{ml}$ dan nilai TPC terendah hari 21 pada perlakuan PO yaitu $2,5 \times 10^{3} \mathrm{CFU} / \mathrm{ml}$ dibandingkan dengan PO yaitu $2,7 \times 10^{3} \mathrm{CFU} / \mathrm{ml}$. Jika ditinjau dari lama penyimpanan yang sama, tanin yang terkandung dalam daun melinjo dapat menghambat kontaminasi mikroba seiring dengan peningkatan persentase air rebusan daun melinjo. Tanin berperan sebagai pendenaturasi protein serta proses pencernaan bakteri dimana mekanisme kerjanya dalam menghambat bakteri dilakukan dengan cara mendenaturasi protein dan merusak membran sel bakteri. Mikroba yang sering ditemukan dalam telur adalah genus Alkaligenes, Pseudomonas, Seratia, Hafnia, Ctrobacter, Proteus, Aeromonas, Flavabacterium, Bacillus, 
Tabel 11. Rataan nilai pH dan Log CFU/ml TPC isi telur ayam ras yang direndam dalam air rebusan daun melinjo (Gnetum gnemon L.)

\begin{tabular}{llllll}
\hline \multirow{2}{*}{ Parameter } & \multirow{2}{*}{ Pengamatan } & \multicolumn{4}{l}{ Perlakuan } \\
\cline { 3 - 6 } & & $P 0$ & $P 1$ & $P 2$ & $P 3$ \\
\hline \multirow{2}{*}{ pH Telur } & Hari ke-14 & $7,60 \pm 0,17^{b}$ & $7,45 \pm 0,11^{b}$ & $7,05 \pm 0,07^{a}$ & $6,99 \pm 0,09^{a}$ \\
\multirow{2}{*}{ Log CFU/mI TPC Isi } & Hari ke-21 & $7,72 \pm 0,06^{b}$ & $7,27 \pm 0,13^{b}$ & $7,14 \pm 0,28^{a}$ & $7,12 \pm 0,28^{a}$ \\
Telur & Hari ke-14 & $2,66 \pm 0,20$ & $2,55 \pm 0,13$ & $2,53 \pm 0,19$ & $2,51 \pm 0,17$ \\
\hline
\end{tabular}

Micrococcus, Streptococcus, dan coliform (Ali, 2005). Berdasarkan Standar Nasional Indonesia (SNI) 2897-2008, telur memiliki kualitas mikrobiologis yang baik dan aman untuk dikonsumsi adalah kurang dari $1 \times 10^{5} \mathrm{CFU} / \mathrm{ml}$ (SNI 2897, 2008). Dari hasil penelitian, nilai TPC yang didapatkan masih dalam taraf aman yaitu kurang dari $1 \times 10^{5} \mathrm{CFU} / \mathrm{ml}$.

\section{Kesimpulan}

Berdasarkan hasil penelitian disimpulkan bahwa konsentrasi 30\% - $45 \%$ air rebusan daun melinjo mempengaruhi karakteristik organoleptik rasa dan aroma telur ayam ras. Perendaman telur dalam air rebusan daun melinjo dapat mempertahankan $\mathrm{pH}$ dalam kisaran 6,99-7,45, meningkatkan warna kuning telur dan total mikroba penambahan $45 \%$ air rebusan daun melinjo lebih rendah dibanding $15 \%$ dan $30 \%$.

\section{Daftar Pustaka}

Aditama. 2005. Mempelajari Sifat - Sifat Melinjo Selama Penyimpanan dengan Menggunakan Gamping. Institut Pertanian Bogor, Bogor.

BSNI. 2008. Badan Standar Nasional Indonesia : Metode Pengujian Cemaran Mikroba dalam Daging, Telur dan Susus, serta Hasil Olahannya SNI 2897-2008. Badan Standarisasi Nasional Indonesia, Jakarta.

Cooper dan Emory. 1996. Metode Penelitian. Erlangga. Jakarta.

Fahrullah, 2012.Pengaruh Penggunaan Probiotik Komersial dan Lama Penyimpanan terhadap Nilai Haugh Unit Telur Asin. Skripsi. Fakultas Peternakan Universitas Hasanuddin Makassar.

Hajrawati, M. Aswar. 2011. Kualitas Interior Telur Ayam Ras Dengan Penggunaan Larutan Daun Sirih (Piper betle) Sebagai Bahan Pengawet. Seminar Nasional Teknologi Peternakan dan Veteriner. Makasar.
Harahap, E.U. 2007. Kajian pengaruh bahan pelapis dan teknik pengemasan terhadap perubahan mutu telur ayam buras selama transportasi dan penyimpanan. Tesis. Bogor ID: Institut Pertanian Bogor.

Hardini. 2000. Pengaruh Suhu dan Lama Penyimpanan Telur Konsumsi dan Telur Biologis Terhadap Kualitas Interior Telur Ayam Kampung. FMIPA Universitas Terbuka.

Haryoto. 2010. Membuat Telur Asin. Kanisius, Yogyakarta.

Indrawan, I.G., I.M. Sukada, I.K. Suada. 2012. Kualitas Telur dan Pengetahuan Masyarakat tentang Penanganan Telur di Tingkat Rumah Tangga. Artikel Telur. ISSN: 2301-784.

Ismarani, 2012. Potensi Senyawa Tanin dalam Menunjang Produksi Ramah Lingkungan. CEFARS : Jurnal Agribisnis dan Pengembangan Wilayah, 3(2): 46-55.

Larmond, E. 1970.Methods for Sensory Evaluation of Food. Food Research Institute. Central Experiment Farm. Ottawa.

Lestari, S., M. Rahmawati, G. Syamsudin. 2012. Pengwetan Telur Dengan Perendaman Ektrak Daun Melinjo (Gnetum gnemon L). Jurnal Sains dan Teknologi, 13(2): 184-189.

Lupitasari, C., R. Somanjaya, O. Imanudin. 2017. Uji Tingkat Kesukaan Telur Ayam Ras Hasil Perendaman Menggunakan Ekstrak Daun Melinjo. Jurnal Ilmu Pertanian dan Peternakan, 5(1): $104-113$.

Muchtadi, T.R, F. Ayustaningwarno, Sugiyono. 2010. Ilmu Pengetahuan Bahan Pangan. Alfabeta, Bandung.

Respati, E., L. Hasanah, S. Wahyuningsih, M. Sehusman, Y. Manurung, Y. Supriyani, Rinawati. 2013. Buletin Konsumsi Pangan. Pusat Data dan Sistem informasi Pertanian, 4 (2): 1-56.

Santoso, U. 2007. Pengaruh Penambahan Ekstrak Daun Katuk terhadap Kualitas Telur 
dan Berat Organ Dalam. Jurnal Sain Peternakan Indonesia , 5(1): 5-10.

Setyaningsih, D.A. 2008. Analisis Sensori untuk Agroindustri. Bogor.

Soekarto, S.T. 2000. Pangan Semi Basah, Keamanan dan Potensinya dalam Perbaikan Gizi Masyarakat. Seminar Teknologi Pangan IV, Bogor.
Soekarto, S. T. 2013. Teknologi penanganan dan pengolahan telur. Alfabeta. Bandung, 210211.

Yulianto, R.R. 2013. Formulasi Produk Minuman Herbal Berbasis Cincau Hitam (Mesona Palustris), Jahe (Zingiber officinale), dan Kayu Manis (Cinnamomum Burmanni). Jurnal Pangan dan Agroindustri 1(1):65-77. 